\title{
A Review of Relationship between Prospective Science Teachers' Attitudes towards Science Education and Their Self-Efficacy ${ }^{1}$
}

\author{
Betül Türer ${ }^{1}$, Halil Kunt ${ }^{1}$ \\ ${ }^{1}$ Faculty of Education, Dumlupinar University, Kutahya, Turkey \\ Correspondence: Halil Kunt, Faculty of Education, Dumlupinar University, 43100, Kutahya, Turkey
}

Received: July 29, 2015 Accepted: August 17, $2015 \quad$ Online Published: September 6, 2015

doi:10.11114/jets.v3i6.983 URL: http://dx.doi.org/10.11114/jets.v3i6.983

\begin{abstract}
In this research, we aim to review relationship between prospective science teachers' attitudes against science education (physics, chemistry, biology, laboratory) and their self-efficacy. Population of the research constitutes 497 students studying Science Education in Department of Elementary Education in Celal Bayar University Faculty of Education. In this research, general survey method is utilized, and "Science Teaching Self-Efficacy Beliefs Scale" developed by Enochs and Rings (1990) and adopted into Turkish by Özkan, Tekkaya and Çakıroğlu (2002) and "Science Teaching Attituted Scale" developed by researchers is used for data collection. For statistical analyses of data collected; descriptive statistical methods (arithmetic mean, \pm standard deviation, frequency, percentage) as well as independent samples T-test, one-way anova LSD test and correlation analysis is used. As concluded from the analyses; a significant difference by gender as well as class level variations is observed in prospective teachers' attitudes towards science education in terms of their general attitude scores, while no observed significant difference is present with respect to variations of their success level and the high school they graduated. Prospective teachers' self-efficacy scores towards science teaching significantly differ by the class level variant, while variants of gender, success status and type of high school they graduated does not make a statistically significant difference. Moreover, a positively significant but low linear correlation between prospective teachers' attitudes towards science education and their self-efficacy points is identified.
\end{abstract}

Keywords: education, science teaching, science self-efficacy, science attitude, prospective teacher

\section{Introduction}

Providing a quality and effective science education in schools will contribute to long-term improvements in science. It is the teachers who are mainly responsible for providing an effective science education and bringing it to the desired level. For this reason, a well-trained and educated teacher is an indicator of a quality education. While teaching a course, investigating the factors that improve students' efficiency and encourage them to learn is also quite important. One of these factors is positive attitude, which inevitably pushes student towards learning. One of the most challenging processes for our teachers is, of course, turning students' attitudes and behaviors on any issue, into positive. According to Bikmaz (2001), it is an individual's positive or negative behavior pattern developed against an object or case. In order for a student to demonstrate positive attitudes towards a teacher of a course, firstly, teacher has to exhibit positive attitude towards its profession and its self-efficacy towards science education needs to be of a high level (Kiremit, 2006). Because students' positive or negative attitudes directly influence their learning process. Their future lives will be affected, based on these attitudes. For this reason, raising individuals who have high level of self-efficacy, exhibiting positive attitudes towards others and are socially beneficial will be realized only when teachers have these exact properties.

\footnotetext{
${ }^{1}$ This research is Betül TÜRER's master's thesis "A Review of Relationship between Prospective Science Teachers' Attitudes towards Science Education and their Self-Efficacy", completed in Dumlupinar University in consultation with Assist. Prof. Dr. Halil KUNT. *This research has been accepted for an oral presentation at the International Conference on Best Practices and Innovations in Education (INOVED 2015), to be held in Izmir, Turkey, on 26-28 October 2015.
} 
Because of these reasons, it is set forth that teachers and prospective teachers should have various competencies in order to bring students during their education and the teaching process up to a satisfactory level, and enable them to learn more effectively. One of this competencies is 'self-efficacy', which is a significant variant to be emphasized with regards to especially teaching profession. Bandura (1977) describes 'self-efficacy'as an individual's belief in self, concerning how and to what extent it may deal with any situation. 'Self-efficacy'is given, in another definition, as recognizing one's capabilities for doing something or having a strong belief in doing so (Zusho and Pintrich, 2003). Based on these descriptions, science education self-efficacy belief is teachers' attitudes towards, and beliefs in, themselves considering realizing science education in an effective and efficient way, positively changing students' behaviors and attitudes, and training highly successful individuals (Özkan, Tekkaya and Çakıroğlu, 2002).

Successfully completing an objective given, or failing to do it, significantly influences a student's comprehension of self-efficacy. This applies to education and training, as it does in all areas. Self-efficacy belief, which is counted as one of the basics of success, impacts the utilized method and technique, effective and permanent teaching for a teacher, and students' stance in the class environment and their participation in the class activities (Üredi and Üredi, 2006). As a result of this, student's success level and quality of the teaching are determined. There are also specific differences between individuals whose understanding of self-efficacy is low and high. According to Senemoğlu (2005), individuals who have a high self-efficacy are patient people who work harder to overcome tasks given to themselves, make great efforts to do them, and stay determined until they are done. On the other hand, individuals who have low self-efficacy the ones who are easily defeated by the obstacles, fail to demonstrate patient and firm stance against when challenges occur- don't have courage enough to try new ways due to the lack of confidence and tend to find the shortest and easiest way of doing, while completing a task (Dorman, 2001; Ritter, Boon and Rubba, 2001). Besides all these, teachers' high self-efficacy belief enables them to efficiently teach, establish effective connections with their students and easily restore a disciplined class environment (Schwarzer and Luszczynska, 2007; Milner, 2002; Pajaers, 2002). Thus, they apply new technique and methods by students' capacity of understanding and awareness, and continuously keep students' attention and motivation high, and raise success rates among students up to the highest point. Bandura (1997), who first coined the concept of self-efficacy, concludes in his researches that the self-efficacy belief is a determinant of individual's new attitudes that it will gain by learning through its own behaviors and the environment, and these attitudes emerge as a result of four factors i.e. social models, complete and true experiences, verbal persuasion, physiological and emotional status, and among these for factors, self-efficacy is mostly influenced by knowledge formed by an individual's own life and experiences.

When literature related with the self-efficacy and attitudes is reviewed, it is seen in general that researches mainly focus on teachers and prospective teachers (Çapa and Çil, 2000; Türkmen, 2002; Umay, 2002; Kahyaoğlu and Yangın, 2007; Akbaş and Çelikkaleli, 2006; Kiremit and Gökler, 2010). Researches made on level of self-efficacy belief include scale-studies on levels and understanding of self-efficacy, impact of a teaching technique on understanding of self-efficacy and academic success, examination of self-efficacy level by different variants, and teachers' self-efficacy issues (Akgün, 2013; Atılboz, 2007; Britner and Pajares, 2006; Akkoyunlu, Orhan and Umay, 2005; Ekici, 2005; Seferoğlu and Akbıyık, 2005; Morrell and Carroll, 2003; Andrew, 1998), studies on attitude towards science and its relationship with success, attitude towards science scale, impact of attitude in science teaching, analysis of attitude towards science by specific variants (Bayrak, 2014; Ekici and Hevedanlı, 2010; Balım, Sucuoğlu and Aydın, 2009; Altunçekiç, Yaman and Koray, 2005; Çapa and Çil, 2000). However, based on these studies in the literature, no study has been found examining relationship between prospective science teachers' attitudes towards science education (biology, physics, chemistry) and their self-efficacy. Science teachers and prospective science teachers who play an important role in dealing with weak sides of science fields in our country. Their level of self-efficacy towards science education should be high and their attitudes should develop in a positive way. For this reason, prospective teachers' personal properties make the difference. So, purpose of this study is to analyze the relationship between prospective science teachers' attitudes towards science education (biology, physics, chemistry) and their self-efficacy. Within the framework of this general purpose of our study, we sought an answer for the following questions.

Do prospective science teachers' attitudes towards science education and their self-efficacy significantly differ by the variants such as;

a) Gender

b) Level of class

c) Success status

d) High school they graduated?

Are there also a significant relationship between prospective science teachers' attitudes towards science education and their self-efficacy? 


\section{Method}

In this research, we used relational screening method in descriptive survey model in order to assess relationship between attitudes of students -who study in department of science teaching- towards science education and their self-efficacy.

\subsection{Study Group}

Study group in the research was formed by all of the 1st, 2nd, 3rd and 4th grade prospective teachers who continued Science Education during 2014-2015 fall semester in Department of Elementary Education in Celal Bayar University Faculty of Education. This research was realized including 497 prospective teachers i.e. 309 female and 188 male.

\subsection{Data Collection Tools}

\subsubsection{Science Teaching Self-efficacy Belief Scale}

In order to measure prospective science teachers' attitudes towards science education, a "science teaching self-efficacy belief scale" was developed by Riggs and Enochs in 1990, and was adopted into Turkish by Özkan, Tekkaya and Çakıroğlu in 2002. This scale that is designed as 5-point likert-type includes 23 statements, i.e. 14 positive and 9 negative. Scale comprises of two sub-dimensions in itself such as Personal Science Teaching Efficacy Belief and Science Teaching Outcome Expectancy.

\subsubsection{Scale of Attitudes towards Science Teaching}

For scale of attitudes towards science education developed by researchers; literature review has been made, studies conducted on attitudes towards science and science education have been reviewed, and scale items found appropriate have been adapted into science education scale used in our research, thus creating the item pool. The scale has been re-designed according to the research object, by bringing the items adapted from the assessment tools together with the statements developed by the researcher who conducted the research. In order to find out whether scale items provided content validity and what their limpidity and efficiency levels were, opinions of three professors from Elementary Education Department of Faculty of Education were taken. Required corrections were made according to the feedback received from the experts, and then a scale draft of 72 items was created and prepared for implementation. This scale consisted of 20 items from each of physics, chemistry and biology sections, and 12 items from field of laboratory. In this research, biology, physics and chemistry sub-dimensions were built for determining science attitudes, just because one student may like physics but may not like chemistry, or vice versa. In such a case, whether student's attitude will be assessed in terms of science or biology or physics is a matter of question. For this reason, we evaluated students' science attitudes both in whole and part in our research.

\subsection{Assessment Tool Structure}

Data collection tool designed to determine prospective science teachers' atittudes towards science education is a 5-point likert-type scale. Likert-type scale is a method that enables researcher to identify subjects' remarks and agreement levels (Özgüven, 1999), and easily and directly assess their attitudes (Kağıtçıbaş1, 1999:136). For this reason, "Scale of Attitudes Towards Science Teaching" is designed with likert method in our research. Answer columns of the items in the scale is organized as "Strongly Agree", "Agree", "Neutral", "Disagree", "Strongly Disagree". Positive items in the scale is scored respectfully beginning from "Strongly Agree" as 5, 4, 3, 2, 1, while negative items are scored as opposite. Since scores in the scale is between 1-5, while closer to 5 means high level of agreement and closer to 1 means low level of agreement.

\subsection{Validity and Reliability Stage of Assessment Tool}

Scale of attitudes towards science education was applied to 187 prospective teachers i.e. 143 females and 44 males, who study in Department of Science Education in Faculty of Education of Kütahya Dumlupınar University. In order to identify structural validity of the scale, factor analysis was made. In order to decide if scale items were appropriate for factor analysis, KMO and Bartlett's test results were used as reference. Scale's KMO value was found 0.77, while Bartlett's test value was around 4369.66. Since KMO value was higher than 0.60 and Bartlett's test was found significant, a factor might be formed out of data (Büyüköztürk, 2014; 126). In other words, these values (KMO >0.60 and Bartlett $\mathrm{p}<.01)$ mean that data are appropriate for factor analysis. As concluded from the factor analysis, in order to identify factor division of the items, their eigen values were checked and those higher than 1 were selected. Because, according to Büyüköztürk (2014), eigen value is a coefficient used to decide amount of factors. In factor analysis, factors, eigen values of which are equal to or higher than 1, are considered important factors. So, in this research, items that have negative effect on items' eigen values together with factor analysis were excluded from the analysis, 41-item scale were put together under 4 factors. Examining line chart in Figure 1, graphical curve was found decreasing between second and third factor. As it is seen, the curve didn't demonstrate sharp fractions and proceeds virtually in the 
same direction after the fourth factor. Sharp downs in the graphic shows factor number and horizontal lines show that contributions of additional variances brought by the factors are close to each other (Büyüköztürk, 2014). From this assessment, it was concluded that factor number in the scale must be four.

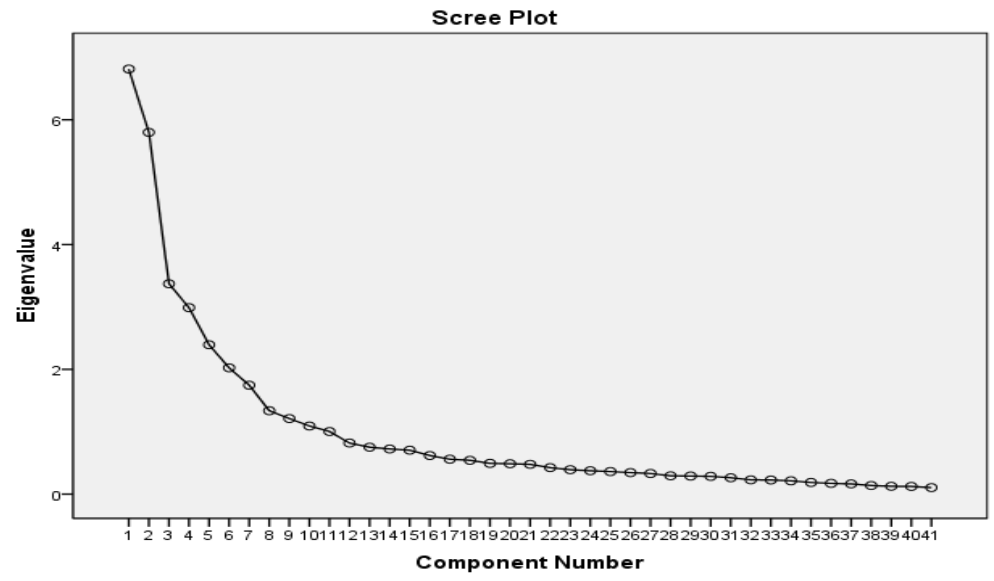

Figure 1. Factor graphic of eigen value of prospective teachers' scale of attitudes towards science teaching

Number of items, eigen values, total variance percentages and cronbach alpha values relevant to the factors found in the research for scale of attitudes which was designed according to the factor analysis results is presented in Table 1.

Table 1. Factor structure and reliability analysis of scale of attitudes towards science education

\begin{tabular}{llllll}
\hline Sub-Dimensions & $\begin{array}{l}\text { Factor } \\
\text { Eigen } \\
\text { Value }\end{array}$ & $\begin{array}{l}\text { Variance } \\
\text { Percentage } \\
(\%)\end{array}$ & $\begin{array}{l}\text { Total } \\
\text { Variance } \\
(\%)\end{array}$ & $\begin{array}{l}\text { Cronbach } \\
\text { alpha }\end{array}$ & Items \\
\hline Factor 1. Attitude towards biology & 6.81 & 16.62 & 16.62 & .88 & $3-6-9-12-15-18-21-24-30-37$ \\
Factor 2. Attitude towards physics & 5.79 & 14.14 & 30.76 & .88 & $1-4-7-10-13-16-19-22-25-28$ \\
Factor 3. Attitude towards chemistry & 3.37 & 8.22 & 38.98 & .84 & $2-5-8-11-14-17-20-23-26-29$ \\
Factor 4. Attitude towards laboratory & 2.98 & 7.28 & 46.27 & .76 & $31-41$ \\
For attitude towards entire scale & & & & .85 & \\
\hline
\end{tabular}

As it may be seen in Table 1, 4 factor values in the scale are higher than 1 and all of the factors constitute $46.27 \%$ of the total variance. These variance values is acceptable for a scale that includes four sub dimensions. Identified variance values are high, which may mean that the relevant concept or structure was measured well to that degree (Büyüköztürk, 2014). Cronbach alpha reliability coefficient of the scale in general is found 0,85 ; attitude towards biology for sub dimensions is .88 , chemistry is .84 , physics is .88 and laboratory is .76 , indicating that scale is applicable and competent. Also, items in the scale are determined by factors. According to these results, it may be stated that scale items are consistent within themselves, and reflect the attitude to be measured. Distribution of the items decided to be included in the scale following the analysis and their factor loads are shown in Table 2.

Table 2. Factor loads of items included in the scale

\begin{tabular}{|c|c|c|c|c|c|c|c|}
\hline \multicolumn{8}{|c|}{ Sub Factors in the Scale } \\
\hline Items & $\begin{array}{l}\text { Factor 1 } \\
\text { (Biology) }\end{array}$ & Items & $\begin{array}{l}\text { Factor } 2 \\
\text { (Physics) }\end{array}$ & Items & $\begin{array}{l}\text { Factor } 3 \\
\text { (Chemistry) }\end{array}$ & Items & $\begin{array}{l}\text { Factor } 4 \\
\text { (Laboratory) }\end{array}$ \\
\hline 18 & .80 & 16 & .73 & 8 & .74 & 40 & .71 \\
\hline 12 & .78 & 13 & .73 & 26 & .72 & 41 & .68 \\
\hline 9 & .70 & 7 & .72 & 11 & .71 & 39 & .67 \\
\hline 15 & .70 & 19 & .70 & 20 & .67 & 38 & .53 \\
\hline $6^{*}$ & .68 & 10 & .69 & 17 & .62 & 33 & .53 \\
\hline 21 & .68 & 25 & .67 & 23 & .61 & 36 & .52 \\
\hline 30 & .65 & 22 & .65 & $2 *$ & .50 & 32 & .51 \\
\hline 27 & .63 & 28 & .57 & 29 & .41 & 31 & .51 \\
\hline $3 *$ & .63 & $4^{*}$ & .56 & 14 & .40 & 34 & .50 \\
\hline 24 & .61 & $1^{*}$ & .52 & $5^{*}$ & .34 & 37 & .44 \\
\hline & & & & & & 35 & .30 \\
\hline
\end{tabular}

(*Negtive items in the scale are scored by reverse reading of the scale.)

As it is seen in Table 2, factor loads of 41 items included in the scale vary between 0.30 and 0.80 . At the end of the analyses, items are listed under four sub dimensions. First, second and third sub dimensions include 10, fourth sub dimension include 11 items. According to the values acquired from the analysis, it is decided that items will be included in the scale, but each item should be included in just one factor. Difference between two items with a high load value is 
tried to be adjusted as at least 10. On condition that an item shows high load value in multiple factors, it is determined as overlapped and excluded from the scale. Based on these attributes, 41 items are found so as to be included in the scale.

\subsection{Analysis of Data}

In this research, relationship between prospective science teachers' attitudes towards science education and their self-efficacy are evaluated. According to the application results received during the development stage of the scale of attitudes towards science education, congruence of data for factor analysis is examined using Kaiser-Meyer-Olkin (KMO) coefficient and Bartlett Test of Sphericity, and is distributed into sub scale dimensions. Then, in order to determine internal consistency of the scale, Cronbach Alpha reliability coefficient is checked, then is proved to be applicable. In order to test if prospective teachers' attitudes towards science education and their self-efficacy differ by gender, class level, success status and type of high school they graduated, t-test and one-way analysis of variance (ANOVA) are applied. Source of significant differences obtained through analysis results is determined using LSD test. SPSS 18.0 bundled statistics program is used for data analysis and level of significance in all analyses is accepted as $\mathrm{p}>0.05$.

\section{Results}

In this section, prospective teachers' attitudes towards science education and their self-efficacy are examined by variants such as gender, success status, class level and high school they graduated. Comparison data of general and sub dimensional scores of prospective teachers' attitudes towards science education and self-efficacy by gender variant is presented in Table 3.

Table 3. T-test results of prospective teachers' attitudes towards science education and their self-efficacy by gender $(\mathrm{n}=497)$

\begin{tabular}{|c|c|c|c|c|c|c|c|}
\hline $\begin{array}{c}\text { Attitude - Self-Efficacy } \\
\text { dimension }\end{array}$ & Gender & $\mathrm{N}$ & $\bar{x}$ & $\mathrm{~S}$ & sd & $\mathrm{t}$ & $\mathrm{p}$ \\
\hline \multirow{2}{*}{ Attitude towards biology } & Female & 309 & 30.00 & 3.38 & 495 & 1.51 & .129 \\
\hline & Male & 188 & 29.50 & 3.72 & & & \\
\hline \multirow{2}{*}{$\begin{array}{l}\text { Attitude towards } \\
\text { physics }\end{array}$} & Female & 309 & 29.34 & 3.42 & 495 & 1.58 & .113 \\
\hline & Male & 188 & 28.83 & 3.52 & & & \\
\hline \multirow[t]{2}{*}{ Attitude towards chemistry } & Female & 309 & 29.00 & 2.94 & 495 & 1.44 & .148 \\
\hline & Male & 188 & 28.57 & 3.48 & & & \\
\hline Attitude & Female & 309 & 40.80 & 6.14 & 495 & 1.46 & .145 \\
\hline towards laboratory & Male & 188 & 39.93 & 6.97 & & & \\
\hline \multirow[t]{2}{*}{ Attitude in general } & Female & 309 & 128.44 & 10.01 & 495 & 2.63 & .009 \\
\hline & Male & 188 & 125.93 & 10.83 & & & \\
\hline \multirow[t]{2}{*}{ Personal Self-Efficacy } & Female & 309 & 35.89 & 3.78 & 495 & 1.06 & .286 \\
\hline & Male & 188 & 36.27 & 3.89 & & & \\
\hline \multirow[t]{2}{*}{ Results expectancy } & Female & 309 & 36.27 & 4.39 & 495 & 1.32 & .185 \\
\hline & Male & 188 & 35.72 & 4.55 & & & \\
\hline \multirow{2}{*}{ Self-efficacy in general } & Female & 309 & 72.16 & 6.39 & 495 & .28 & .773 \\
\hline & Male & 188 & 72.34 & 7.53 & & & \\
\hline
\end{tabular}

Table 4. Anova results of prospective teachers' attitude and self-efficacy scores towards science education by class level $(\mathrm{n}=497)$

\begin{tabular}{|c|c|c|c|c|c|c|c|c|c|c|c|c|c|c|c|}
\hline \multirow{2}{*}{$\begin{array}{c}\text { Attitude - Self-Efficacy } \\
\text { Dimensions }\end{array}$} & \multicolumn{3}{|c|}{ Grade 1} & \multicolumn{3}{|c|}{ Grade 2} & \multicolumn{3}{|c|}{ Grade 3} & \multicolumn{3}{|c|}{ Grade 4} & \multicolumn{3}{|c|}{ Total } \\
\hline & $\mathrm{N}$ & $\bar{x}$ & $\mathrm{~S}$ & $\mathrm{~N}$ & $\bar{x}$ & $\mathrm{~S}$ & $\mathrm{~N}$ & $\bar{x}$ & $\mathrm{~S}$ & $\mathrm{~N}$ & $\bar{x}$ & $\mathrm{~S}$ & $\mathrm{~N}$ & $\bar{x}$ & $\mathrm{~S}$ \\
\hline $\begin{array}{l}\text { Attitude towards } \\
\text { biology }\end{array}$ & 146 & 30.46 & 3.18 & 96 & 29.57 & 3.36 & 96 & 29.47 & 3.82 & 159 & 29.55 & 3.67 & 497 & 29.81 & 3.52 \\
\hline $\begin{array}{l}\text { Attitude towards } \\
\text { physics }\end{array}$ & 146 & 29.51 & 3.24 & 96 & 28.85 & 3.83 & 96 & 29.36 & 3.70 & 159 & 28.86 & 3.26 & 497 & 29.15 & 3.46 \\
\hline $\begin{array}{l}\text { Attitude towards } \\
\text { chemistry }\end{array}$ & 146 & 29.03 & 2.96 & 96 & 28.70 & 3.40 & 96 & 28.37 & 3.16 & 159 & 29.03 & 3.18 & 497 & 28.84 & 3.16 \\
\hline $\begin{array}{l}\text { Attitude towards } \\
\text { laboratory }\end{array}$ & 146 & 42.31 & 6.68 & 96 & 41.59 & 6.03 & 96 & 39.04 & 6.09 & 159 & 38.97 & 6.26 & 497 & 40.47 & 6.48 \\
\hline $\begin{array}{l}\text { Attitude in } \\
\text { general }\end{array}$ & 146 & 130.20 & 8.80 & 96 & 127.61 & 10.94 & 96 & 125.36 & 9.46 & 159 & 126.22 & 11.43 & 497 & 127.49 & 10.39 \\
\hline $\begin{array}{c}\text { Personal } \\
\text { Self-Efficacy }\end{array}$ & 146 & 36.30 & 4.28 & 96 & 36.43 & 3.51 & 96 & 35.63 & 3.98 & 156 & 35.78 & 3.43 & 497 & 36.06 & 3.82 \\
\hline Expected Result & 146 & 37.26 & 4.78 & 96 & 35.51 & 4.44 & 96 & 35.91 & 3.58 & 156 & 35.38 & 4.44 & 497 & 36.06 & 4.45 \\
\hline $\begin{array}{c}\text { Self-efficacy in } \\
\text { general }\end{array}$ & 146 & 73.79 & 8.04 & 96 & 71.95 & 6.60 & 96 & 71.55 & 5.06 & 156 & 71.38 & 6.51 & 497 & 72.23 & 6.83 \\
\hline
\end{tabular}


From the results of the analysis, when prospective science teachers' attitudes towards science education are compared by gender variant, a statistically significant difference is seen in support of female prospective teachers, only in the case of scores obtained from the entire scale $(\mathrm{p}=0.009)$. This finding may be interpreted as "gender is determinant on prospective teachers' attitudes towards science education". However, for prospective teachers' attitudes towards science education, when their scores from sub dimensions of biology, physics, chemistry and laboratory are compared, there is no significant difference by gender. Besides this, it is identified that prospective teachers' self-efficacy scores towards science education don't demonstrate a significant difference by gender variant, either. In other words, gender factor is not determinant on prospective teachers' self-efficacy beliefs towards science education. Prospective teachers' scores from entire and sub dimensions of scales of their attitudes and self-efficacy towards science education by class level variant are presented in Table 4.

It can be inferred from the analysis results that highest score of prospective teachers' attitudes towards science education by class level belongs to 1st grade students, while the lowest belongs to 3rd grades. When sub dimensions of their attitudes towards science are considered, prospective teachers' attitudes towards laboratory are the highest, while the lowest are towards biology. Also, it is determined that prospective teachers' self-efficacy towards science teaching gradually decreases beginning from the first year of education, and prospective teachers achieve highest scores in self-efficacy scale by class level during the first year, and lowest scores during the fourth. One-way variance analysis (ANOVA) is applied in order to determine if there is a statistically significant difference between prospective teachers' attitude and self-efficacy scores towards science education by class level variant. Results of scores derived from scales' entirety and sub dimensions are presented in Table 4.1.

Table 4.1. Variance analysis results of prospective teachers' attitude and self-efficacy scores towards science education by class levels

\begin{tabular}{|c|c|c|c|c|c|c|c|}
\hline $\begin{array}{c}\text { Attitude - } \\
\text { Self-Efficacy } \\
\text { dimensions }\end{array}$ & & $\begin{array}{l}\text { Squares } \\
\text { Total }\end{array}$ & sd & $\begin{array}{c}\text { Squares } \\
\text { Mean }\end{array}$ & $\mathrm{F}$ & $\mathrm{p}$ & $\begin{array}{l}\text { Significant } \\
\text { Difference }\end{array}$ \\
\hline \multirow{3}{*}{$\begin{array}{l}\text { Attitude towards } \\
\text { biology }\end{array}$} & Inter-group & 88.63 & 3 & 29.54 & \multirow[t]{3}{*}{2.39} & \multirow[t]{3}{*}{.067} & \multirow[t]{3}{*}{ - } \\
\hline & Intra-group & 6072.95 & 493 & 12.31 & & & \\
\hline & Total & 6161.59 & 493 & & & & \\
\hline \multirow{3}{*}{$\begin{array}{l}\text { Attitude towards } \\
\text { physics }\end{array}$} & Inter-group & 44.78 & 3 & 14.92 & \multirow[t]{3}{*}{1.22} & \multirow[t]{3}{*}{.29} & \multirow[t]{3}{*}{ - } \\
\hline & Intra-group & 5916.89 & 493 & 12,00 & & & \\
\hline & Total & 5961.68 & 496 & & & & \\
\hline \multirow{3}{*}{$\begin{array}{l}\text { Attitude towards } \\
\text { chemistry }\end{array}$} & Inter-group & 33.75 & 3 & 11.25 & \multirow[t]{3}{*}{1.12} & \multirow[t]{3}{*}{.33} & \multirow[t]{3}{*}{-} \\
\hline & Intra-group & 4934.01 & 493 & 10,008 & & & \\
\hline & Total & 4967.75 & 496 & & & & \\
\hline Attitude & Inter-group & 1169.54 & 3 & 389.84 & 9.77 & .000 & $1-3$ \\
\hline towards & Intra-group & 19664.39 & 493 & 39.88 & & .000 & $1-4$ \\
\hline \multirow[t]{2}{*}{ laboratory } & \multirow[t]{2}{*}{ Total } & \multirow[t]{2}{*}{20833.93} & \multirow[t]{2}{*}{496} & & & .005 & $2-3$ \\
\hline & & & & & & .001 & $2-4$ \\
\hline \multirow{2}{*}{ Attitude in general } & Inter-group & 1765.58 & 3 & 588.52 & \multirow{2}{*}{5.60} & \multirow[t]{2}{*}{.001} & $1-3$ \\
\hline & Intra-group & 51804.66 & 493 & 105.08 & & & $1-4$ \\
\hline \multirow{4}{*}{$\begin{array}{c}\text { Personal } \\
\text { Self-efficacy }\end{array}$} & Total & 53570.24 & 496 & & & & \\
\hline & Inter-group & 51.62 & 3 & 17.20 & \multirow[t]{3}{*}{1,175} & \multirow[t]{3}{*}{.31} & \multirow[t]{3}{*}{ - } \\
\hline & Intra-group & 7219.72 & 493 & 14.64 & & & \\
\hline & Total & 7271.34 & 496 & & & & \\
\hline \multirow[t]{3}{*}{ Results expectancy } & Inter-group & 312.24 & 3 & 104.08 & \multirow[t]{3}{*}{5.37} & \multirow[t]{3}{*}{.001} & $1-2$ \\
\hline & Intra-group & 9545.80 & 493 & 19.36 & & & $1-3$ \\
\hline & Total & 9858.04 & 496 & & & & $1-4$ \\
\hline \multirow{3}{*}{$\begin{array}{l}\text { Self-efficacy in } \\
\text { general }\end{array}$} & Inter-group & 552.78 & 3 & 174.26 & \multirow[t]{3}{*}{3.78} & \multirow[t]{3}{*}{.01} & $1-2$ \\
\hline & Intra-group & 22672.91 & 493 & 45.99 & & & $1-3$ \\
\hline & Total & 23195.69 & 496 & & & & $1-4$ \\
\hline
\end{tabular}

Based on the variance analysis result, prospective teachers' attitude scores towards science education and sub dimension scores towards laboratory are found statistically significant by class level variant. It is seen that, according to the LSD test results identifying to which class levels this significance applies, 1st grade students have higher mean scores compared to 3rd and 4th grade students, while 2nd grades have higher mean scores compared to 3rd and 4th grades, in the case of sub dimension attitudes towards laboratory. Apart from this, prospective teachers' sub dimension of attitudes towards biology, physics and chemistry by class levels variant demonstrates no significant difference. This indicates that teaching the laboratory oriented courses is far more effective than teaching theoretical courses, considering prospective teachers' attitudes towards science education. Also, prospective teachers' self-efficacy towards science education and sub dimension scores of the result expectancy are found statistically significant. It is determined that, according to the LSD test results identifying to which group this significance applies, 1st grade students' self-efficacy scores towards science education are higher than the others. Prospective teachers' scores from entire and sub dimensions of scales of 
their attitudes, and self-efficacy towards science education by success status variant are presented in Table 5 .

Table 5. Analysis of prospective teachers' attitude and self-efficacy scores towards science education by success status

\begin{tabular}{|c|c|c|c|c|c|c|c|c|c|c|}
\hline $\begin{array}{l}\text { Attitude - } \\
\text { Self-Efficacy } \\
\text { Dimensions }\end{array}$ & $\mathrm{N}$ & $1-1.99$ & $\mathrm{~S}$ & $\mathrm{~N}$ & $2-2.99$ & $\mathrm{~S}$ & $\mathrm{~N}$ & $3-4$ & $\mathrm{~S}$ & $\mathrm{p}$ \\
\hline $\begin{array}{l}\text { Attitude towards } \\
\text { biology }\end{array}$ & 16 & 30.56 & 2.80 & 228 & 29.31 & 3.99 & 107 & 29.87 & 2.76 & .521 \\
\hline $\begin{array}{l}\text { Attitude towards } \\
\text { physics }\end{array}$ & 16 & 29.37 & 4.66 & 228 & 29.04 & 3.72 & 107 & 28.84 & 2.94 & .805 \\
\hline $\begin{array}{l}\text { Attitude towards } \\
\text { chemistry }\end{array}$ & 16 & 28.12 & 3.70 & 228 & 28.83 & 3.47 & 107 & 28.70 & 2.60 & .679 \\
\hline $\begin{array}{l}\text { Attitude towards } \\
\text { laboratory }\end{array}$ & 16 & 42.50 & 4.80 & 228 & 39.63 & 6.55 & 107 & 39.45 & 5.69 & .183 \\
\hline Attitude in general & 16 & 129.18 & 7.10 & 228 & 126.07 & 11.33 & 107 & 126.58 & 10.07 & .521 \\
\hline $\begin{array}{l}\text { Personal } \\
\text { Self-Efficacy }\end{array}$ & 16 & 35.25 & 11.57 & 228 & 36.05 & 5.77 & 107 & 35.74 & 5.90 & .58 \\
\hline Expected Result & 16 & 35.0 & 4.63 & 228 & 35.61 & 4.15 & 107 & 35.54 & 4.34 & .851 \\
\hline $\begin{array}{l}\text { Self-efficacy in } \\
\text { general }\end{array}$ & 16 & 72.31 & 11.57 & 228 & 71.67 & 5.77 & 107 & 71.29 & 5.90 & .777 \\
\hline
\end{tabular}

In the application, success scores of prospective teachers who were 1st grade students in the department of science education couldn't be derived ( $\mathrm{n}=146)$. This is because, application was made before the term was complete, so students didn't have year-end success scores. For this reason, comparison of attitudes towards science education and success status is calculated on 351 individuals. According to these findings, prospective teachers having the highest mean scores in terms of attitudes towards science education by success status variant are those with the lowest success status. When prospective teachers' attitudes towards science education are examined by their sub dimensions, the highest mean score comes from sub dimension of attitudes towards laboratory. Moreover, when the entire scale of self-efficacy towards science teaching by prospective teachers' success status is taken into account; prospective teachers, whose success status is $1-1.99$, have the highest mean score $(\bar{x}=72.31)$, while those with a success status of 3-4 have the lowest mean score $(\bar{x}=71.29)$. When it comes to scale's sub dimensions of self-efficacy and results expectancy, those with a success status score of 2-2.99 have the highest mean score $(\bar{x}=36.05, \bar{x}=35.61)$, and those with a score of 1-1.99 have the lowest mean score $(\bar{x}=35.25, \bar{x}=35.0)$. As a result of the variance analysis conducted in order to determine if prospective teachers' attitude and self-efficacy scores towards science education by success status variant, and if their sub dimensions are significant, no statistically significant difference was found among F values. In other words, it may be said that success levels are not effective on prospective teachers' attitudes and self-efficacy towards science education. Prospective teachers' scores from entire and sub dimensions of scales of their attitudes and self-efficacy towards science education by high school graduated variant are presented in Table 6 .

Table 6. Anova results of prospective teachers' attitude and self-efficacy scores towards science education by high school graduated $(\mathrm{n}=497)$

\begin{tabular}{|c|c|c|c|c|c|c|c|c|c|c|c|c|c|}
\hline \multirow{2}{*}{$\begin{array}{c}\text { Attitude - } \\
\text { Self-Efficacy } \\
\text { Dimensions } \\
\end{array}$} & \multicolumn{3}{|c|}{ General High School } & \multicolumn{3}{|c|}{ Anatolian High School } & \multicolumn{3}{|c|}{$\begin{array}{l}\text { Anatolian Teacher } \\
\text { Training High School }\end{array}$} & \multicolumn{3}{|c|}{$\begin{array}{l}\text { Vocational High } \\
\text { School }\end{array}$} & \multirow[b]{2}{*}{$\mathrm{p}$} \\
\hline & $\mathrm{N}$ & $\bar{x}$ & $\mathrm{~S}$ & $\mathrm{~N}$ & $\bar{x}$ & $\mathrm{~S}$ & $\mathrm{~N}$ & $\bar{x}$ & $\mathrm{~S}$ & $\mathrm{~N}$ & $\bar{x}$ & $\mathrm{~S}$ & \\
\hline $\begin{array}{l}\text { Attitude towards } \\
\text { biology }\end{array}$ & 254 & 29.58 & 3.66 & 153 & 30.35 & 3.27 & 41 & 29.31 & 3.67 & 49 & 29.71 & 3.27 & .13 \\
\hline $\begin{array}{l}\text { Attitude towards } \\
\text { physics }\end{array}$ & 254 & 29.0 & 3.35 & 153 & 29.10 & 3.54 & 41 & 29.51 & 4.0 & 49 & 29.75 & 3.33 & .49 \\
\hline $\begin{array}{l}\text { Attitude towards } \\
\text { chemistry }\end{array}$ & 254 & 28.93 & 3.08 & 153 & 29.02 & 3.23 & 41 & 28.39 & 2.99 & 49 & 28.18 & 3.46 & .29 \\
\hline $\begin{array}{l}\text { Attitude towards } \\
\text { laboratory }\end{array}$ & 254 & 39.81 & 6.62 & 153 & 41.24 & 6.02 & 41 & 41.68 & 5.78 & 49 & 40.48 & 7.37 & .10 \\
\hline $\begin{array}{l}\text { Attitude in general } \\
\text { Personal Self- }\end{array}$ & 254 & 126.62 & 10.60 & 153 & 129.04 & 10.21 & 41 & 127.85 & 10.48 & 49 & 126.89 & 9.41 & .14 \\
\hline & 25 & 36. & 3. & 15 & 36. & 3. & 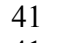 & & 4.7 & 4 & & 3. & .786 \\
\hline Expected Result & 254 & 35.65 & 4.21 & 153 & 36.50 & 4.77 & 41 & 37.39 & 4.65 & 49 & 35.73 & 4.25 & .056 \\
\hline $\begin{array}{c}\text { Self-efficacy in } \\
\text { general }\end{array}$ & 254 & 71.93 & 7.10 & 153 & 72.60 & 6.44 & 41 & 72.92 & 7.99 & 49 & 72.08 & 5.54 & .71 \\
\hline
\end{tabular}

It is seen from the analysis results that graduates of Anatolian High School received the highest scores from the entire scale of prospective science teachers' attitudes towards science education, and General High School graduates received the lowest. Also, when prospective teachers' attitudes towards science education are examined by their sub dimensions, the highest mean score comes from sub dimension of attitudes towards laboratory. Apart from this, prospective teachers' scores of self-efficacy towards science education by the high school they graduated are the highest for graduates of 
Anatolian Teacher Training High School, while they are the lowest in the case of General High School graduates. One-way variance analysis (ANOVA) is applied in order to determine if there is a statistically significant difference between prospective teachers' attitude and self-efficacy scores towards science education by the high school they graduated variant. As a result of the variance analysis conducted in order to determine if prospective teachers' attitude and self-efficacy scores towards science education by the high school they graduated variant and if their sub dimensions are significant, no statistically significant difference was found among F values. In other words, it may be said that the high school they graduated is not effective on prospective teachers' attitudes and self-efficacy towards science education. Relationship between prospective teachers' attitudes and self-efficacy towards science education is presented in Table 7. Table 7. Correlation analysis results of prospective teachers' attitudes and self-efficacy towards science education

\begin{tabular}{ccc}
\hline & & Attitude \\
\hline Self-efficacy & $\mathrm{r}$ & .123 \\
& $\mathrm{p}$ & .006 \\
& $\mathrm{~N}$ & 497 \\
\hline
\end{tabular}

When values on the table are analyzed, a positively significant but low linear correlation between prospective teachers' attitudes towards science education and their self-efficacy is identified $(\mathrm{p}<.01)$. So, when determination coefficient $\left(\mathrm{r}^{2}\right.$ $=.015)$ related to self-efficacy is taken into consideration, it may be said that just a small proportion $(1 \%)$ of the whole stems from the attitude towards science education. Relationship between prospective teachers' sub dimensions of attitudes and self-efficacy towards science education is presented in Table 7.1.

Table 7.1. Correlation analysis results of prospective teachers' sub dimensions of attitudes and self-efficacy towards science education

\begin{tabular}{|c|c|c|c|c|c|c|}
\hline & & Biology & Physics & Chemistry & Laboratory & $\begin{array}{r}\text { Total } \\
\text { Self-Efficacy } \\
\end{array}$ \\
\hline \multirow[t]{3}{*}{ Biology } & Pearson Correlation & 1 & .081 & $.528^{* *}$ & $.414^{* *}$ & .075 \\
\hline & Sig. (2-tailed) & & .071 & .000 & .000 & .094 \\
\hline & $\mathrm{N}$ & 497 & 497 & 497 & 497 & 497 \\
\hline \multirow[t]{3}{*}{ Physics } & Pearson Correlation & .081 & 1 & $.296^{* *}$ & $-.111^{*}$ & .043 \\
\hline & Sig. (2-tailed) & .071 & & .000 & .013 & .336 \\
\hline & $\mathrm{N}$ & 497 & 497 & 497 & 497 & 497 \\
\hline \multirow[t]{3}{*}{ Chemistry } & Pearson Correlation & $.528^{* *}$ & $.296^{* *}$ & 1 & .082 & .056 \\
\hline & Sig. (2-tailed) & .000 & .000 & & .067 & .213 \\
\hline & $\mathrm{N}$ & 497 & 497 & 497 & 497 & 497 \\
\hline \multirow[t]{3}{*}{ Laboratory } & Pearson Correlation & $.414^{* *}$ & $-.111^{*}$ & .082 & 1 & $.130^{* *}$ \\
\hline & Sig. (2-tailed) & .000 & .013 & .067 & & .004 \\
\hline & $\mathrm{N}$ & 497 & 497 & 497 & 497 & 497 \\
\hline \multirow[t]{3}{*}{ Total Self-Efficacy } & Pearson Correlation & .075 & .043 & .056 & $.130^{* *}$ & 1 \\
\hline & Sig. (2-tailed) & .094 & .336 & .213 & .004 & \\
\hline & $\mathrm{N}$ & 497 & 497 & 497 & 497 & 497 \\
\hline
\end{tabular}

**. Correlation is significant at the 0.01 level.

*. Correlation is significant at the 0.05 level.

There is a low linear relationship between prospective teachers' self-efficacy and their attitudes towards sub dimensions of biology, physics and chemistry that is statistically insignificant but is significant in terms of sub dimension of laboratory. So, when determination coefficient $\left(\mathrm{r}^{2}=.015\right)$ related to prospective teachers' self-efficacy is taken into consideration, it may be said that just a small proportion (1\%) of the whole stems from the attitude towards science education. Based on Pearson correlation coefficients inter se sub dimensions of attitudes towards science education, there is a significant intermediate-level linear relationship between their attitudes towards chemistry and biology ( $\mathrm{r}=53$ ), and there is a significant low-level linear relationship between their attitudes towards physics ( $\mathrm{r}=29)$. There is a negatively significant intermediate-level linear relationship between their attitudes towards laboratory and biology $(\mathrm{r}=41)$, and there is a negatively significant low-level linear relationship between their attitudes towards physics $(\mathrm{r}=$ -.11). Absolute value of correlation coefficient is interpreted high between 0.70-1.00; intermediate between 0.69-0.30; low between 0.29-0.00 (Büyüköztürk, 2008).

\section{Discussion}

Science teachers and prospective teachers should have high and positive levels of self-efficacy, and attitudes towards their vocation in order to be effective and qualified science teachers, at the first step, in the education and training environment, and effectively transfer their knowledge, skills and capabilities to their students. Most effective way of achieving this is their pre-service that is provided in faculties of education prior to working. Prospective science teachers are expected to positively develop their attitudes and self-efficacy towards science education following the education process they are into in faculties of education. Based on these statements, this research aimed to assess the relationship between prospective science teachers' attitudes and self-efficacy towards science education. With this 
purpose in mind, prospective science teachers' attitudes towards science education and their self-efficacy are examined by variants such as gender, success status, class level and the high school they graduated.

Comparing prospective teachers' attitudes towards science education by gender variant, it is identified that prospective teachers' general attitudes towards science education show a significant difference in support of female students, while sub dimensions of attitudes towards physics, chemistry, biology and laboratory do not show a significant difference by gender variant. Based on literature research on gender variant, it is determined that elementary and secondary level students' attitudes towards science education differ, and also gender is one of the most effective variants that change attitudes towards science education (George, 2000). Moreover, when researches conducted on prospective teachers are examined, it is concluded that gender leads to a significant difference in terms of science education (Dhinsa and Chung, 2003; She and Fisher, 2002; Kızılcık et al, 2007; Tekbıyık and İpek, 2007; Çakmak, 2008; Özden, Kara and Tekin, 2008; Buaraphan, 2011). These results are in parallel with the results of our research. Females rather than males are colloquially seen more inclined for teaching, and that may also be the reason why females embrace this profession and develop more positive attitudes. Based on other researches in the literature, however, teachers' and prospective teachers' attitudes towards science education do not demonstrate a significant difference by gender variant (Özkan, Tekkaya and Çakıroğlu, 2002; Sarıkaya, 2004; Denizoğlu, 2008). This situation contradicts our results, and it may be because different sampling groups are involved.

Based on prospective teachers' self-efficacy towards science teaching by gender variant, scores taken from scale's entirety and sub dimensions of personal self-efficacy and results expectancy do not show statistically significant difference. Results obtained from the research are in parallel with results of various researches in the literature (Kurtuluş and Çavdar, 2010; Denizoğlu, 2008; Şensoy and Aydoğdu, 2008; Akbaş and Çelikkaleli, 2006; Arsal, 2006; Mudasiru, 2005; Chao, 2001). It may be interpreted as a proof that, nowadays, females and males face less inequalities in their social and vocational lives compared to the past, and differences of the past have disappeared in time. Apart from this, results of our research contradicts results of some other researches in the literature. So, considering the results, there are significant differences in terms of self-efficacy beliefs of male or female prospective teachers (depending on the researcher) (Kalaian and Freeman, 1994; Bleicher, 2004; Üredi and Üredi, 2006; Tekbıyık and İpek, 2007). It may be an indicator that females face and have more difficulties, they embrace their profession better, and their self-efficacy develops positively because of their will to succeed, compared to males.

There is a significant difference in comparison of prospective teachers' general attitude scores towards science education and sub dimension of attitudes towards laboratory by class level variant, while there is no statistically significant difference found in terms of the sub dimensions of attitudes towards physics, chemistry and biology. Based on Anova test, difference in terms of class levels is determined between first grade students and both third and fourth grade students, in support of the first grades. At the same time, it is found in sub dimensions of attitudes towards laboratory that first as well as second grades show significant difference in support of third and fourth grade students. Based on analysis results, the reason why first and second grade prospective teachers have more positive attitudes towards science education compared with third and fourth grade students may be because beginner prospective teachers are more interested and eager to learn science topics and are more idealist prior to university education; however as senior year approaches, exam anxiety, preoccupation of assignment on graduation and anxiety of failing to suit their professions themselves may have lead them to develop a negative attitude. Moreover, there is a statistically significant difference in terms of prospective teachers' attitudes in terms of sub dimensions; and the reason might be that prospective teachers want to teach through laboratory courses and think that learning is more meaningful, permanent and enjoying if courses are taught through learning by experience rather than theoretical courses. Results of some of the researches in the literature conducted on this issue are in parallel with our research (Kahyaoğlu and Yangın, 2007; Tekbıyık and İpek, 2007; Çakmak, 2008). Apart from this, there are some results in the literature, showing that senior prospective teachers have more positive attitudes towards science education (Türkmen ve Bonnstetter, 1999; Denizoğlu, 2008).

Prospective teachers' general self-efficacy and sub dimension of results expectancy towards science education show statistically significant difference in terms of class level variant, while there is no statistically significant difference on personal self-efficacy dimension. It is concluded from the results of analysis that a significant difference is found among beginner prospective teachers and others, and is in support of the beginners. This result supports our research, being in parallel with particular researches in the literature (Altunçekiç, Yaman and Koray 2005; Gencel-Evin and Köse 2011; Karaduman and Emrahoğlu, 2011). Then, the reason why first grade prospective teachers' self-efficacy are higher than the others may be the freshman's excitement to access new data, will to learn, vocational discoveries and desire of "can-do", all contributing to positive improvement of self-efficacy. However, findigs of our research contradicts results of some researches in the literature (Üredi and Üredi, 2006; Vural-Ekinci and Hamurcu, 2008). Based on particular researches in the literature, as class level increases self-efficacy increases, too. It may be inferred from this situation that 
as the class level increases, the confidence in self on application of vocational know-how and the trust in self based on the knowledge of most of the topics increase.

As a result of the analyses conducted on prospective teachers' attitudes towards science education by success status and the high school they graduated variants, no statistically significant difference is found. This is reflected in a number of researches in the literature, showing parallelism with our research and supporting the results acquired (Akçay-Okur, 2014; Kahyaoğlu and Yangın, 2007; Saracaloğlu et al, 2002).

As a result of the analyses conducted on prospective teachers' self-efficacy scores towards science teaching by their success status and the high school they graduated variant, no statistically significant difference is found. This is reflected in a number of researches in the literature, showing parallelism with our research and supporting the results acquired (Yaman et al, 2004; Altunçekiç, Yaman and Koray, 2005; Şensoy and Aydoğdu, 2008). However, this research contradicts findings of Karaduman and Emrahoğlu (2011). Based on the results of the research, type of high school which prospective teachers graduated does not differ by sub dimension of their personal self-efficacy, while showing significant difference by sub dimension of results expectancy. This situation may be a conclusion of having worked with various sampling groups.

A positively significant but low linear correlation between prospective teachers' attitudes towards science education and their self-efficacy scores is identified. Based on Pearson correlation coefficients inter se sub dimensions of attitudes towards science education, there is a significant intermediate-level linear relationship between their attitudes towards chemistry and biology $(\mathrm{r}=53)$, and there is a significant low-level linear relationship between their attitudes towards physics $(\mathrm{r}=29)$. There is a negatively significant intermediate-level linear relationship between their attitudes towards laboratory and biology $(\mathrm{r}=41)$, and there is a negatively significant low-level linear relationship between their attitudes towards physics $(\mathrm{r}=-.11)$. These findings show that there is a positive linear relationship between prospective teachers' attitudes towards biology and chemistry as well as laboratory and biology, while there is a negative linear relationship between their attitudes towards physics. It may be concluded from this situation that prospective teachers enjoy biology laboratory, while they do not like physics laboratory.

Based on the results of research; in order to increase prospective teachers' attitudes and self-efficacy towards science education, professors may do and lead different practices, ensuring prospective teachers do not abstain from science courses. It may be advised to prospective teachers that they should ingratiate science; science teaching is not difficult and it can be successfully realized. This research is conducted with prospective teachers studying in department of science teaching in Celal Bayar University, and is limited within variants of gender, class level, success status, the type of high school graduated. Similar researches may be conducted to obtain more general results, using different samples and variants, and this research can be applied across Turkey on a regional basis.

\section{References}

Akbaş, A., \& ve Çelikkaleli, Ö. (2006). Sınıf öğretmeni adaylarının fen öğretimi öz-yeterlik inançlarının cinsiyet, öğrenim türü ve üniversitelerine göre incelenmesi. Mersin Üniversitesi Eğitim Fakültesi Dergisi, 2, 98-110.

Akçay-Okur, N. (2014). Okul öncesi öğretmeni adaylarının fene yönelik tutumlarının çeşitli değişkenlere göre incelenmesi. The Journal of Academic Social Science Studies, 30, 325-336. http://dx.doi.org/10.9761/JASSS2580

Akgün, F. (2013). Öğretmen adaylarının web pedagojik içerik bilgileri ve öğretmen öz-yeterlik algıları ile ilişkisi. Trakya Üniversitesi Ĕ̈itim Fakültesi Dergisi, 3, 48-58.

Akkoyunlu, B., Orhan, F., \& ve Umay, A. (2005.) Bilgisayar öğretmenleri için bilgisayar öğretmenliği öz-yeterlik ölçeği geliştirme çalışması. Hacettepe Üniversitesi Ĕ̈itim Fakültesi Dergisi, 29, 8.

Altunçekiç, A., Yaman, S., \& ve Koray, Ö. (2005). Öğretmen adaylarının öz-yeterlik inanç düzeyleri ve problem çözme becerileri üzerine bir araştırma (Kastamonu ili örneği) Kastamonu Eğitim Dergisi, 13, 93-102.

Andrew, S. (1998). Self - efficacy as a predictor of academic performance in science. Journal of advanced nursing, 27, 596-603. http://dx.doi.org/10.1046/j.1365-2648.1998.00550.x

Arsal, Z. (2006). Self-efficacy beliefs of teacher candidates on using a computer in teaching. In annual meeting of the 6thInternational Educational Technologies Conference, Cyprus.

Atılboz, N. G. (2007). Öğrenme halkası modelinin biyoloji öğretmen adaylarının difüzyon ve osmoz konuların ögrenmeleri, biyoloji öğretimine yönelik öz yeterlik inançları ve tutumları üzerine etkileri (doctoral dissertation). YÖK Tez Merkezi (207021).

Balım-Günay, A., Sucuoğlu, H., \& ve Aydın, G. (2009). Fen ve teknolojiye yönelik tutum ölçeğinin geliştirilmesi. Pamukkale Üniversitesi Eğitim Fakültesi Dergisi, 1, 25. 
Bandura A. (1997). Self-Efficacy: The Exercise of Control. New York: Freeman

Bandura, A. (1977). Self-efficacy: toward a unifying theory of behavioral change. Psychological review, 84, 191. http://dx.doi.org/10.1037/0033-295X.84.2.191

Bayrak-Karadeniz, B. (2014). Öğrenme stilleri ve fen ve teknoloji dersine yönelik tutumlar üzerine bir araştırma. Kuramsal Eğitimbilim Dergisi, 7, 1-15.

Bıkmaz H. F. (2001). İlköğretim 4. ve 5. sinıf öğrencilerinin fen bilgisi dersindeki başarılarını etkileyen faktörler (doctoral dissertation). YÖK Tez Merkezi (99935).

Bleicher, R. E. (2004). Revisiting the STEBI-B: Measuring self-efficacy in preservice elementary teachers. School Science \& Mathematics, 104, 383-391. http://dx.doi.org/10.1111/j.1949-8594.2004.tb18004.x

Britner, S. L., \& Pajares, F. (2006). Sources of science self - efficacy beliefs of middle school students. Journal of Research in Science Teaching, 43, 485-499. http://dx.doi.org/10.1002/tea.20131

Buaraphan, K. (2011). The impact of the standard-based science teacher preparation program on pre-service science teachers' attitudes toward science teaching. Türk Fen Eğitimi Dergisi, 8, 61-78.

Büyüköztürk, Ş. (2014). Sosyal bilimler için veri analizi el kitabı. (20. Basım) Ankara: Pegem Akademi.

Çakmak, M. (2008). Fen bilgisi öğretmen adaylarının laboratuvar tutumları ile fen bilgisine yönelik tutumları arasindaki ilişkinin değerlendirilmesi (master's thesis). YÖK Tez Merkezi.

Çapa, Y., \& Çil, N. (2000). Öğretmen adaylarının öğretmenlik mesleğine yönelik tutumlarının farklı değişkenler açısından incelenmesi. Hacettepe Üniversitesi Eğitim Fakültesi Dergisi. 18, 69-73.

Chao, W. Y. (2001). Using computer self-efficacy scale to measure the attitudes of Taiwan elementary preservice teachers toward computer technology (China). Florida Atlantic University.

Denizoğlu, P. (2008). Fen bilgisi öğretmen adaylarının fen bilgisi öğretimi öz-yeterlik inanç düzeyleri, öğrenme stilleri ve fen bilgisi ögretimine yönelik tutumları arasındaki ilişsinin değerlendirilmesi (master's thesis). YÖK Tez Merkezi (217183).

Dhindsa, H. S., \& Chung, G. (2003). Attitudes and achievement of bruneian science students. International Journal Science Education, 25, 907-922. http://dx.doi.org/10.1080/09500690305025

Dorman, J. P. (2001). Associations Between Classroom Environment And Academic Efficacy, Learning Environments Research, 4, 243-257. http://dx.doi.org/10.1023/A:1014490922622

Ekici, G. (2005). Eğitim fakültesi öğrencilerinin öğretmenlik öz-yeterlik inançlarını etkileyen faktörler. XIV. Ulusal Eğitim Bilimleri Kongresi, Pamukkale Üniversitesi Eğitim Fakültesi, 28-30 September 2005, Denizli.

Ekici, G., \& Hevedanlı, M. (2010). Lise öğrencilerinin biyoloji dersine yönelik tutumlarının farklı değişkenler açısından incelenmesi. Türk Fen Ĕ̈itimi Dergisi, 7, 4.

Gencel-Evin, İ., \& Köse, A. (2011). Fen bilgisi öğretmen adaylarının öğrenme stilleri, öğrenme ve ders çalışma stratejileri ile fen bilgisi öğretimi öz yeterlik inançları arasındaki ilişki. Eğitimde Kuram Ve Uygulama 7, 311-333.

George, R. (2000). Measuring change in students' attitudes toward science over time: an application of latent variable growth modeling. Journal of Science Education and Technology, 9, 213-225. http://dx.doi.org/10.1023/A:1009491500456

Kağıtçıbaşı, C. (1999). Yeni İnsan ve İnsanlar Sosyal Psikolojiye Giriş. İstanbul: Evrim Yayınevi, 10. Edition, Sosyal Psikoloji Dizisi:1

Kahyaoğlu, M., \& Yangın, S. (2007) İlköğretim sınıf öğretmenliği, fen bilgisi ve matematik öğretmen adaylarının fen bilgisi öğretimine yönelik tutumları. ZKÜ Sosyal Bilimler Dergisi, 3, 203-220.

Kalaian, H. A., \& Freeman, D. J. (1994). Gender differences in self-confidence and educational beliefs among secondary teacher candidates. Teaching and Teacher Education, 10, 647-658. http://dx.doi.org/10.1016/0742-051X(94)90032-9

Karaduman, B., \& Emrahoğlu, N. (2011). Sınıf öğretmeni adaylarının bazı değişkenler açısından fen öğretimi öz-yeterlik inanç düzeylerinin ve sonuç beklentilerinin incelenmesi üzerine bir araştırma. Türk Fen Eğitimi Dergisi, $8,9$.

Karasar, N. (2013). Bilimsel araştırma yöntemleri. (25. Edition) Nobel yayıncılık, Ankara

Kiremit, H. Ö. (2006). Fen bilgisi öğretmenliği ögrrencilerinin biyoloji ile ilgili öz yeterlik inançlarının karşılaştırılması (doctoral dissertation). YÖK Tez Merkezi (186547). 
Kiremit-Özenoğlu, H., \& Gökler, İ. (2010). Fen bilgisi öğretmenliği öğrencilerinin biyoloji öğretimi ile ilgili öz-yeterlik inançlarının karşılaştııılması. Pamukkale Üniversitesi Ĕgitim Fakültesi Dergisi, 27, 41-54.

Kızılcık, Ş. H., Temiz, B. K., Tan, M., \& İngeç-Kandil, Ş. (2007). Sözel bölüm öğretmen adaylarının fen bilimlerine, fen eğitimine ve teknolojiye karşı tutumlarının araştırılması. Eğitim ve Bilim, 32, 146.

Kurtuluş N., \& Çavdar, O. (2010). Öğretmen adaylarının fen öğretimine yönelik öz yeterlikleri. E-Journal Of New Word Science Academy, 5, 3.

Milner, H. R. (2002). A case study of an experienced English teacher's self-efficacy and persistence through" crisis" situations: Theoretical and practical considerations. The High School Journal,86, 28-35. http://dx.doi.org/10.1353/hsj.2002.0020

Morrell, P. D., \& Carroll, J. B. (2003). An Extended Examination of Preservice Elementary Teachers' Science Teaching Self - $\quad$ Efficacy. School Science and Mathematics, 103, 246-251. http://dx.doi.org/10.1111/j.1949-8594.2003.tb18205.x

Mudasiru, O. Y. (2005), An investigation into teachers' self-efficacy in implementing computer education in Nigerian secondary schools. Meridian: A Middle School Computer Technologies Journal, 8, 4.

Özata, H. (2007). Öğretmenlerin öz-yeterlik algllarının ve örgütsel yenileşmeye ilişkin görüşlerinin araştırılması (master's thesis). YÖK Tez Merkezi (226118).

Özgüven, İ. E. (1999). Psikolojik Testler. Ankara: Psikolojik Danışma, Rehberlik ve Eğitim Merkezi (PDREM).

Özkan, Ö., Tekkaya, C., \& Çakıroğlu, J. (2002), Fen bilgisi aday öğretmenlerin fen kavramlarını anlama düzeyleri, fen öğretimine yönelik tutum ve öz yeterlik inançları. V. Ulusal Fen Bilimleri ve Matematik Eğitimi Kongresi, 16-18 September 2002. Orta Doğu Teknik Üniversitesi, Ankara

Pajares, F. (2002). Gender and perceived self-efficacy in self-regulated learning. Theory into practice, 41, 116-125. http://dx.doi.org/10.1207/s15430421tip4102_8

Ritter, J., Boone, W., \& Rubba, P. (2001). Development of An Instrument To Assess Prospective Elementary Teacher SelfEfficacy Beliefs About Equitable Science Teaching And Learning (SEBEST). Journal of Science Teacher Education, 12, 175-198. http://dx.doi.org/10.1023/A:1016747713585

Saracaloğlu, S., Serin, O., \& Bozkurt, N. (2002). Öğretmen adaylarının fen bilimlerine yönelik tutumları ile başarıları arasındaki ilişki. Ege Eğitim Dergisi, 1, 76-85.

Sarıkaya, H. (2004). Sınıf öğretmeni adaylarının bilgi düzeyleri, fen öğretimine yönelik tutumları ve öz yeterlik inançları (unpublished master's thesis). ODTÜ, Fen Bilimleri Enstitüsü.

Schwarzer, R., \& Luszczynska, A. (2007). Self-efficacy. In M. Gerrard \& K. D. McCaul (Eds.), Health behavior constructs: Theory, measurement, and research. National Cancer Institute Website.

Seferoğlu, S. S., \& Akbıyık, C. (2005). İlköğretim öğretmenlerinin bilgisayara yönelik öz-yeterlik algıları üzerine bir çalı̧̧ma. Eurasian Journal of Educational Research, 19, 89-101.

Senemoğlu, N. (2005). Gelişim Öğrenme ve Öğretim-Kuramdan Uygulamaya. (12. Edition ). Ankara: Gazi Kitabevi.

Şensoy, Ö., \& Aydoğdu, M. (2008). Araştırma soruşturma tabanlı öğrenme yaklaşımının fen bilgisi öğretmen adaylarının fen öğretimine yönelik öz-yeterlik inanç düzeylerinin gelişimine etkisi. Gazi Üniversitesi, Gazi Eğitim Fakültesi Dergisi, 28, 69-93.

Serin, O. (2001). Lisans ve lisansüstü düzeydeki fen grubu öğrencilerinin problem çözme becerileri fen ve bilgisayar yönelik tutumları ile başarıları arasındaki ilişki (unpublished master's thesis). Dokuz Eylül Üniversitesi Eğitim Bilimleri Enstitüsü, İzmir.

She, H. C., \& Fisher, D. (2002). Teacher communication behavior and its association with students' cognitive and attitudinal outcomes in science in taiwan. Journal Of Research In Sclence Teaching, 39, 63-78. http://dx.doi.org/10.1002/tea.10009

Tekbıyık, A., \& İpek, C. (2007). Sınıf öğretmeni adaylarının fen bilimlerine yönelik tutumları ve mantıksal düşünme becerileri. Yüzüncü Yll Üniversitesi, Eğitim Fakültesi Dergisi, 4, 102-117.

Türkmen, L. (2002). Sınıf öğretmenliği 1. sınıf öğrencilerinin fen bilimleri ve fen bilgisi öğretimine yönelik tutumları. Hacettepe Üniversitesi Ĕ̈itim Fakültesi Dergisi, 23, 218-228.

Türkmen, L., \& Bonnstetter, R. (1999). A study of Turkish preservice science teachers' attitudes toward science and science teaching. Paper Presented At The Annual Convention Of National Assocation of Research in Science 


\section{Teaching,}

Umay, A. (2002). İlköğretim matematik öğretmenliği programının matematiğe karşı öz yeterlik algısına etkisi. V. Ulusal Fen Bilimleri ve Matematik Ĕgitimi Kongresi, 16-18 September 2002. Orta Doğu Teknik Üniversitesi, Ankara.

Üredi I., \& Üredi L. (2006). Sınıf öğretmeni adaylarının cinsiyetlerine, bulundukları sınıflara ve başarı düzeylerine göre fen öğretimine ilişkin öz yeterlik inançlarının karşılaştırılması. Yeditepe Üniversitesi Eğitim Fakültesi Dergisi, 1 , $1-8$.

Vural-Ekinci, D., \& Hamurcu, H. (2008). Okul öncesi öğretmen adaylarının fen öğretimi dersine yönelik öz-yeterlik inançları ve görüşleri. İlkögretim Online, 7, 456-467.

Yaman, S., Cansüngü-Koray, Ö., \& Altunçekiç, A. (2004). Fen bilgisi öğretmen adaylarının öz yeterlik inanç düzeylerinin incelenmesi üzerine bir araştırma. Türk Eğitim Bilimleri Dergisi, 2, 355-366.

Zusho, A., Pintrich, P. R., \& Coppola, B. (2003). Skill and will: The role of motivation and cognition in the learning of college chemistry. International Journal of Science Education, 25, 1081-1094. http://dx.doi.org/ $10.1080 / 0950069032000052207$

\section{$(\mathrm{cc}) \mathrm{EY}$}

This work is licensed under a Creative Commons Attribution 3.0 License. 